\title{
Trump Administration and the Politics of Visa Denial to Nigerian Citizens
}

\author{
Jibrin Ubale Yahaya, $\mathrm{PhD}$ \\ Department of Political Science, National Open University of Nigeria (NOUN)
}

\begin{abstract}
President Trump on January $31^{\text {st }} 2020$ has added six countries to his list of nations facing stringent travel restrictions, a move that will virtually block immigration from Africa's most populous nation, Nigeria, and from Myanmar, where the Muslim minority is fleeing genocide. Beside Nigeria, three other African countries, Eritrea, Sudan and Tanzania, will face varying degrees of restrictions, as will one former Soviet state, Kyrgyzstan, Myanmar's. All six countries have substantial Muslim populations. The total number of countries now on the restricted travel list stands at 13. Immigrant visas, issued to those seeking to live in the United States, will be banned from Nigeria, Myanmar, Eritrea and Kyrgyzstan. The ban will also prevent immigrants from Sudan and Tanzania from moving to the United States through the diversity visa lottery, which grants green cards to as many as 50,000 people a year. The paper would uses secondary source of data from relevant publications. The researcher was of the view that most of these countries with US Visa restriction have issues of security problems and are mainly Muslim countries. The paper was of the view that if these countries need to have respect and international recognition the government of these countries must take the issue of insecurity and fighting terrorism as a priority agenda so that they cannot be isolated as unsecured countries among countries of the world.
\end{abstract}

Keywords: Immigrant, Visa, Terrorism and Insecurity.

DOI: $10.7176 / \mathrm{JLPG} / 97-11$

Publication date:May $31^{\text {st }} 2020$

\section{Introduction}

According to Almasy, S (2017) the US travel ban denotes a series of executive actions enacted by Donald Trump as President of the United States in 2017. First, Executive Order 13769 placed stringent restrictions on travel to the United States for citizens of Iran, Iraq, Libya, Somalia, Sudan, Syria, and Yemen. Following protests and legal challenges, a second order, Executive Order 13780, amended some provisions of the first order, and removed Iraq from the list. Finally, Presidential Proclamation 9645 added restrictions on Chad, North Korea, and Venezuela, while Sudan was removed. Six of the eight affected countries are predominantly Muslim (Bier, 2017)

On 31 January, 2020, the Trump administration announced the expansion of the travel ban on six more countries. However this ban only affects certain visas for residents in countries of Eritrea, Kyrgyzstan, Myanmar, Nigeria, Sudan, and Tanzania. This extended is expected to be implemented February $21^{\text {st }}, 2020$. (BBC News, 2020)

The new US travel restrictions will significantly affect four African countries, as well as Kyrgyzstan and Myanmar ( Kaster,2020) the travel bans imposed by Donald Trump on four African countries have prompted anger, concern, disappointment and resignation on the continent. The measures significantly restrict visas that could end with permanent residency in the US for Eritreans and Nigerians, and end so-called "diversity" migration visas from Tanzania and Sudan.

Chad Wolf, (2020) the acting homeland security secretary, said the countries hit by the new measures failed to meet US security and information-sharing standards. Kyrgyzstan and Myanmar were also included in the list.

Trump has made cracking down on immigration a focus of his 2020 re-election campaign, and his travel ban policy is popular with Republican supporters - but experts say that it will harm US efforts to roll back the growing influence of Russia and China in Africa.

A previous ban, introduced in 2017, barred nearly all immigrants and travelers from three African countries - Libya, Somalia and Chad - and five elsewhere. The policy sparked outrage and was revised amid court challenges before the US Supreme Court ultimately upheld it in June 2018.

Matthew T, (2020) an associate fellow with the Africa programme at Chatham House, London, said:

"I think we are seeing a domestic political agenda steamrolling foreign policy concerns, Eritrea is a minor economic and diplomatic player on the continent, but is strategically situated on the Red Sea. The repressive, authoritarian regime has been courted by Moscow, which wants to build a major logistics base there to rival the vast US base in nearby Djibouti."

Given the two weeks between the early speculation about the countries on the expanded ban and the final announcement there might have been some expectation a country like Nigeria's with higher profile in Africa might have been able to talk itself off the list via diplomatic backchannels while fixes were being made.

But Nigeria's shortcomings notwithstanding, Owezi, S (2020) sees Trump's decision as a "political" move. 
"This is an election year. There's impeachment going on. (Trump) is doing this just to make his base happy."

\section{Statement of Problem}

Visas issued in 2016 for the 7 countries affected by section 3 of the executive order. The total number shown by size, and color breaks down type of visa has been reduced (Visa Report, 2016)

The key provisions of executive orders 13769 and 13780 cite to paragraph (f) of Title 8 of the_United States Code $\S 1182$, which discusses inadmissible aliens. Paragraph (f) states:

Whenever the President finds that the entry of any aliens or of any class of aliens into the United States would be detrimental to the interests of the United States, he may by proclamation, and for such period as he shall deem necessary, suspend the entry of all aliens or any class of aliens as immigrants or non immigrants, or impose on the entry of aliens any restrictions he may deem to be appropriate.

The act that underlies this, known as the Immigration and Nationality Act of 1952 (a.k.a. the McCarranWalter Act), was amended by the Immigration and Nationality Act of 1965 (a.k.a. the Hart-Celler Act), which included a provision stating

No person shall receive any preference or priority or be discriminated against

in the issuance of an immigrant visa because of the person's race, sex, nationality, place of birth, or place of residence.

The language in the INA of 1965 is among the reasons District of Maryland judge Chuang issued a temporary restraining order blocking Section 2(c) of Executive Order 13780 (Bier, 2017)

The US has announced it is expanding its curbs on immigration to include six more countries, including Nigeria, Africa's most populous nation. Citizens from Nigeria, Eritrea, Sudan, Tanzania, Kyrgyzstan and Myanmar will now be blocked from obtaining certain types of visas.

People from those countries will still be able to visit the US as tourists. In 2018 the US issued twice as many immigration visas to Nigeria than to the other five nations combined. An official US visa office said the new measures were the result of failures by the six countries to meet US security and information-sharing standards.

As part of its justification for imposing the ban, the administration cited concerns about Nigeria's security standards, and increasing terrorist threats. It claims it wants to see Nigeria improve information-sharing with the US and Interpol to help identify criminals and terrorists.

The fallout over the Trump administration's decision on Friday $31^{\text {st }}$, January 2020 to restrict immigration from four additional African countries has continued, with officials and citizens from the nations affected openly criticizing the US's new policy.

Under the new rules, which are due to take effect on February $21^{\text {st }}, 2020$ six new countries including Eritrea, Nigeria, Sudan and Tanzania, as well as Kyrgyzstan and Myanmar, will face various visa restrictions. Unlike President Donald Trump's 2017 travel ban, which sparked outrage around the world for primarily targeting Muslims, it is not a total travel ban. Nationals from Sudan and Tanzania will be banned from participating in the diversity visa lottery scheme, while visas which can lead to permanent residency will no longer be issued to Nigerians and Eritreans.

Nigerian President Muhammadu Buhari, on $3^{\text {rd }}$ February 2020, said he wanted the country to have "productive relations" with the US. He also set up a committee to "study and address" the new visa requirements.

However, opposition leader from People Democratic Party (PDP) Atiku Abubakar was more forthcoming in his response, saying the US should instead "consider adopting measures that individually target those in government who have failed in their duties, rather than target the entire Nigerian population."

The government of Eritrea also denounced the measures as an "unfriendly act," with the Ministry of Information branding the ban a political move that ignores Eritrea's own attempts to stop what it called "automatic asylum" and "systematic depopulation" of the country.

But the group of visas targeted raises questions about the rationale for the ban. "The category that he is banning, it doesn't make any sense as applicants for immigrant visas, except those reuniting with their spouses, often go through years of rigorous vetting.

Owezi, S (2020) said "People on temporary visas don't do rigorous screenings like permanent residents, clients in Maryland has been waiting for a decade to be reunited with his brother in Lagos; now, owing to the ban, the brothers will have to wait even longer. "If the US wants to make a difference, they could have banned Nigerian officials, instead of banning innocent people."

\section{Research Questions}

The paper has the following three questions to be asked:

i. Why President Trump make this pronouncement very close to US election period?

ii. Does President Trump consult these affected countries before taking this decision?

iii. What would be the consequences of US economy as a result of largest African economy Nigeria in the list of the ban countries? 


\section{Research Objective}

The main objectives of the research is to study the politics behind the President Trump declaration on additional countries on the ban list and the economic implication of his action because of involving Nigeria as part of the list.

\section{Research Methodology}

This paper has uses the secondary source of data by using various literatures from previous data on the issues of US data denial to other different countries in the world.

\section{Definitions of Concept}

US visa specimen

The visa policy of the United States deals with the requirements which a foreign national wishing to enter the United States must meet to obtain a visa, which is a permit to travel to, enter, and remain in the United States. Visitors to the United States must obtain a visa from one of the United States diplomatic missions unless they come from one of the visa-exempt countries or Visa Waiver Program countries. The same rules apply to Puerto Rico and the United States Virgin Islands while different rules apply to Guam, Northern Mariana Islands and American Samoa.(AITA,2017)

\section{Entry visas}

A foreign national wishing to enter the U.S., Puerto Rico or the U.S. Virgin Islands must obtain a visa unless he or she satisfies one of the following conditions:

- a permanent resident of the U.S.

- a citizen of the Compact of Free Association states: Federated States of Micronesia, the Marshall Islands, and Palau

- a citizen of Canada, including those applying for TN status at the border

- a British Overseas Territories citizen with a connection to Bermuda

- a citizen of one of the thirty-nine countries that are part of the Visa Waiver Program

- a citizen of The Bahamas or a British Overseas Territories citizen with a connection to British Virgin Islands, Cayman Islands or Turks and Caicos Islands, under certain conditions

- holding a Form I-512 ("Authorization for Parole of an Alien into the United States")

Mexican citizens may travel to the U.S. without a passport under limited circumstances if holding a Border Crossing Card and seeking to enter the U.S. for less than seventy-two hours while remaining in the "border zone". Border Crossing Card, (2019)

While there are about one hundred eighty-five different types of visas, According to Grossman, N (2009) has cited that there are two main categories of U.S. visas:

- Nonimmigrant visa: for temporary visits such as for tourism, business, work, visiting family, or studying.

- Immigrant visa: for people to immigrate to the United States. At the port of entry, the immigrant visa holder is processed for a permanent resident card (I-551, often known as a 'green card'). Upon endorsement with a CBP admission stamp, it serves as temporary I-551 evidencing permanent residence for one year. A child with an IR-3 or IH-3 visa will automatically become a United States citizen upon admission to the United States and be processed for a certificate of citizenship (N-560).

In order to immigrate, one should either have an immigrant visa or have a dual intent visa, which is one that is compatible with making a concurrent application for permanent resident status, or having an intention to apply for permanent residence.

Entering the U.S. on an employment visa may be described as a three-step process in most cases. First, the employer files an application with U.S. Citizenship and Immigration Services requesting a particular type of category visa for a specific individual. If the employer's application is approved, it only authorizes the individual to apply for a visa; the approved application is not actually a visa. The individual then applies for a visa and is usually interviewed at a U.S. embassy or consulate in the native country. If the embassy or consulate grants the visa, the individual is then allowed to travel to the U.S. At the border crossing, airport, or other point of entry into the U.S., the individual speaks with an officer from U.S. Customs and Border_Protection to request admission to the U.S. If approved, the individual may then enter the U.S. (FAQs, 2010)

Contrary to a popular misconception, a U.S. visa does not authorize the alien's entry into the United States, nor does it authorize the alien's stay in the U.S. in a particular status. A U.S. visa only serves as a preliminary permission given to the alien to travel to the United States and to seek admission to the United States at a designated port of entry. The final admission to the United States in a particular status and for a particular period of time is made at the port of entry by a U.S. Customs and Border Protection (CBP) officer. For aliens entering the U.S. in a nonimmigrant visa status, these details are recorded by the CBP officer on the alien's Form I-94 (Form I-94W 
for citizens of the Visa Waiver Program countries entering the U.S. for short visits), which serves as the official document authorizing the alien's stay in the United States in a particular non-immigrant visa status and for a particular period of time. (IATA, 2016) Fifty thousand additional visas (immigrant visas DV-1, DV-2, DV-3) are available each year under the Diversity Immigrant Visa Program (also known as the green card lottery).

\section{The 2016 presidential campaign}

On December 7, 2015, as a candidate for president, Donald Trump called for "a total and complete shutdown of Muslims entering the United States until our country's representatives can figure out what the hell is going on. According to Taylor J, (2015) has cite that the comments of Trump were condemned by several of his competitors for the Republican nomination, including Chris Christie, Jeb Bush, Marco Rubio, and Lindsey Graham, as well as by several Republican state party chairmen, civil rights activist Ibrahim Hooper of the Council on AmericanIslamic Relations (CAIR), and Democratic candidates for president Bernie Sanders and Martin O'Malley.

\section{Executive actions}

- $\quad$ Executive Order 13769 (January 27, 2017) - The original travel ban.

- Executive Order 13780 (March 6, 2017) - The second and revised travel ban superseding the original travel ban. This ban was effective for only 90 days.

- Presidential Proclamation 9645 (September 24, 2017) - A third travel ban to replace the second one, which expired after 90 days.

- Presidential Proclamation 9723 (April 10, 2018) - A proclamation removed the travel restrictions on Chad.

Source: (Fabbian, 2018)

In the days after the first executive order was issued, White House Press Secretary Sean Spicer objected to the characterization of the executive order as a "travel ban". However, Trump himself referred to his actions as a "travel ban' (Marcin, 2017) In early May 2017, Spicer was asked by a reporter "If this White House is no longer calling this a 'Muslim ban'...why does the president's website still explicitly call for 'preventing Muslim immigration'?" After the question was asked, the text "DONALD J. TRUMP STATEMENT ON PREVENTING MUSLIM IMMIGRATION" was removed from Trump's campaign website (Barbash, 2017)

All three travel bans were challenged in court, and Presidential Proclamation 9645 and its accompanying travel ban was upheld in the Supreme Court. According Lemire, J (2020) in January 2020, the Trump Administration announced plans for an expansion of the travel ban.

\section{Effect on banned countries}

Over 135 million people fall under the ban. The Muslim countries are the ones who are most affected by this, the biggest being Iran with more than an 80 million population. As been cited by Gladstone, R (2018) it was 12 months after the implementation of the travel ban in 2018, only 537 immigrant visas were issued for individuals born in Iran. Whereas in 2017, it was 6643 visas were issued to Iranian born individuals, depicting a staggering $92 \%$ decrease in the 12 months following the travel ban. Iran wasn't the only Muslim country affected by the ban; other countries faced a similar effect. 12 months after the travel ban was in effect, Somalia experienced an $86 \%$ reduction in the number of immigrant visas and Yemen saw a decrease by $83 \%$, Libya saw an $80 \%$ decrease and Syria $77 \%$. However, the per month immigrant visas issued to non-Muslim countries on the travel ban barely changed. Actually, the number of visas issued to North Koreans increased by $40 \%$.

The expanded travel ban will suspend issuance of visas that can lead to permanent residency for nationals of Eritrea, Kyrgyzstan, Myanmar, and Nigeria. The expanded travel ban also stated that Sudanese and Tanzanian nationals will no longer be issued with diversity visas. (BBC News, 2020)

\section{List of countries under current travel ban}

The countries affected by the travel ban according to the BBC News (2020): Ban on all visas including visa for immigrants, tourism, business, medical treatment, etc.

- Iran

- Libya

- Somalia

- Syria

- Yemen

Only ban or restriction for immigrant visas and officials (Venezuela)

- Venezuela

- North Korea

- $\quad$ Eritrea (expected to be implemented February 21st 2020) 
- Kyrgyzstan (expected to be implemented February 21st 2020)

- Myanmar (expected to be implemented February 21st 2020)

- $\quad$ Nigeria (expected to be implemented February 21st 2020)

- Sudan (expected to be implemented February 21st 2020)

- Tanzania (expected to be implemented February 21st 2020)

Executive Order 13769, titled protecting the Nation from Foreign Terrorist Entry into the United States, politically labeled as a Muslim ban by detractors or a travel ban

The supporters of the ban were using executive order by United States President Donald Trump. Except for the extent to which it was blocked by various courts, it was in effect from January 27, 2017, until March 16, 2017, when it was superseded by Executive Order 13780. Executive Order 13769 lowered the number of refugees to be admitted into the United States in 2017 to 50,000, suspended the U.S. Refugee Admissions Program (USRAP) for 120 days, suspended the entry of Syrian refugees indefinitely, directed some cabinet secretaries to suspend entry of those whose countries do not meet adjudication standards under U.S. immigration law for 90 days, and included exceptions on a case-by-case basis. The Department of Homeland Security (DHS) lists these countries as Iran, Iraq, Libya, Somalia, Sudan, Syria, and Yemen. More than 700 travelers were detained, and up to 60,000 visas were "provisionally revoked" (NPR, 2017)

The signing of the order provoked widespread condemnation and protests and resulted in legal intervention against the enforcement of the order with some calling it a "Muslim ban" because Trump had previously called for temporarily banning Muslims from America soon after the 2015 San Bernardino terrorist attack (a call he reiterated after the Orlando nightclub shooting six months later, and because all of the affected countries had a Muslim majority. The US Ban (2018) has cited that a nationwide temporary restraining order (TRO) was issued on February 3, 2017 in the case Washington v. Trump, which was upheld by the United States Court of Appeals for the Ninth Circuit on February 9, 2017. Consequently, the Department of Homeland Security stopped enforcing portions of the order and the State Department re-validated visas that had been previously revoked. Later, other orders (Executive Order 13780 and Presidential Proclamation 9645) were signed by Trump and superseded order 13769. On June 26, 2018, the U.S. Supreme Court upheld the third executive order (Presidential Proclamation 9645 ) and its accompanying travel ban in a 5-4 decision, with the majority opinion being written by Chief Justice John Roberts.

\section{Restrictions by Obama administration}

In 1986, the Visa Waiver Program was initiated by President Ronald Reagan, allowing alien nationals of select countries to travel to the United States for up to 90 days without a visa, in return for reciprocal treatment of U.S. nationals. By 2016, the program had been extended to 38 countries. According to Visa waiver (2017) cited that in 2015, Congress passed a Consolidated Appropriations Act to fund the government, and Obama signed the bill into law. The Visa Waiver Program Improvement and Terrorist Travel Prevention Act of 2015, which was previously passed by the House of Representatives as H.R. 158, was incorporated into the Consolidated Appropriations Act as Division O, Title II, Section 203. The Trump administration's executive order relied on H.R. 158, as enacted. The terrorist prevention Act of 2015 has highlighted how the Visa Waiver Program Improvement and Terrorist Travel Prevention Act originally affected four countries: Iraq, Syria, and countries on the State Sponsors of Terrorism list (Iran and Sudan). Foreigners who were nationals of those countries, or who had visited those countries since 2011, were required to obtain a visa to enter the United States, even if they were nationals or dual-nationals of the 38 countries participating in the Visa Waiver Program.

Boyle, D (2016) has cited Libya, Yemen, and Somalia were added later as "countries of concern" by Secretary of Homeland Security Jeh Johnson during the Obama administration.

The executive order refers to these countries as "countries designated pursuant to Division O, Title II, Section 203 of the 2016 consolidated Appropriations Act". Prior to this, in 2011, additional background checks were imposed on the nationals of Iraq (Arango, 2011)

Trump's press secretary Sean Spicer cited these existing restrictions as evidence that the executive order was based on outstanding policies saying that the seven targeted countries were "put first and foremost" by the Obama administration (Shelbourne, 2017)

Kessher, G, (2017) has cited that fact-checkers at PolitiFact.com, The New York Times, and The Washington Post said the Obama restrictions cannot be compared to this executive order because they were in response to a credible threat and were not a blanket ban on all individuals from those countries, and concluded that the Trump administration's statements about the Obama administration were misleading and false.

Trump campaign and administration statements before the order's signing

Further information: Donald Trump presidential campaign, $2016 \S$ Temporary Muslim ban proposal; and Immigration policy of Donald Trump $\S$ Proposed Muslim immigration ban 
Number of refugees admitted from October 1, 2016 through January 31, 2017, and state settled in. National origin for 7 countries in Executive Order colored; all other countries grouped, in gray (USDS, 2017)

Donald Trump became the U.S. president on January 20, 2017. He has long claimed that terrorists are using the U.S. refugee resettlement program to enter the country. Greenwood, M (2018) has cited that as s a candidate Trump's "Contract with the American Voter" pledged to suspend immigration from "terror-prone regions"

Boyer, D (2017) has cited how Trump-administration officials then described the executive order as fulfilling this campaign promise. Speaking of Trump's agenda as implemented through executive orders and the judicial appointment process, White House chief strategist Steve Bannon stated: "If you want to see the Trump agenda it's very simple. It was all in the [campaign] speeches. He's laid out an agenda with those speeches, with the promises he made, and job every day is to just to execute on that. He's maniacally focused on that."

During his initial election campaign Trump had proposed a temporary, conditional, and "total and complete" ban on Muslims entering the United States. Trump Temporary Order (2017) has highlighted that Trump proposal was met by opposition of U.S. politicians including Mike Pence and James Mattis.

Visas by country in 2016, showing number issued by size, and countries selected in the Executive Order in orange, all others in green

On June 12, 2017 in reference to the Orlando nightclub shooting that occurred on the same date, Trump used Twitter to renew his call for a Muslim immigration ban. On June 13 Trump proposed to suspend immigration from "areas of the world" with a history of terrorism, a change from his previous proposal to suspend Muslim immigration to the U.S; the campaign did not announce the details of the plan at the time, but Jeff Sessions, an advisor to Trump campaign on immigration, said the proposal was a statement of purpose to be supplied with details in subsequent months (Pence,2017)

On July 15, 2016 Pence, who as governor of Indiana attempted to suspend settlement of Syrian refugees to the state but was prevented from doing so by the courts, said that decision was based on the fall 2015 FBI assessment that there is risk associated with bringing in refugees. Pence cited the infiltration of Iraqi refugees in Bowling Green Kentucky who were arrested in 2011 for attempting to provide weapons to ISIS and Obama's suspension of the Iraqi refugee program in response as precedent for a U.S. President's "temporarily suspending immigration from countries where terrorist influence and impact represents a threat to the United States". (Donal, 2016)

On July 17, Trump (with Pence) participated in an interview on 60 Minutes that sought to clarify whether Trump's position on a Muslim ban had changed; when asked whether he had changed position on the Muslim ban, he said: "—no, I - Call it whatever you want. We'll call it territories, OK?" Trump's response would later be interpreted by Judge Brinkema of the Eastern District of Virginia as acknowledging "the conceptual link between a Muslim ban and the [executive order]" in her ruling finding the executive order likely violates the Establishment Clause of the U.S. Constitution.(Tafani,2016)

In a speech on August 4 to a Maine audience Trump called for stopping the practice of admitting refugees from among the most dangerous places in the world; Trump specifically opposed Somali immigration to Minnesota and Maine, describing the Somali refugee program, which has resettled tens of thousands of refugees in the U.S., as creating "a rich pool of potential recruiting targets for Islamic terror groups". In Minnesota 10 men of Somali or Oromo family backgrounds were charged with conspiring to travel to the Middle East to join ISIS and 20 young men traveled to Somalia to join a terror group in 2007. Trump went on to list alleged terrorist plots by immigrants from Somalia, Yemen, Iraq, and Syria, along with incidents of alleged terrorist plots or acts by immigrants from countries not among the seven specified by the eventual executive order such as Pakistan, Afghanistan, the Philippines, Uzbekistan, and Morocco(Donal,2016)

In a speech on August 15 Trump listed terrorism attacks in the United States (9/11; the 2009 Fort Hood shooting; the Boston Marathon bombing; the shootings in Chattanooga, Tennessee; and the Orlando nightclub shooting as justification for his proposals for increased ideological testing and a temporary ban on immigration from countries with a history of terrorism; on this point, the Los Angeles Times' analysis observed Trump "failed to mention that a number of the attackers were U.S. citizens, or had come to the U.S. as children". (The same analysis also acknowledged an act of Congress eventually cited to in the executive order was probably what Trump would attempt to use in implementing such proposals. No deaths in the U.S. had been caused by extremists with family backgrounds in any of the seven countries implicated by the executive order as of the day before it was signed. In the speech, Trump vowed to task the departments of State and Homeland Security to identify regions hostile to the United States such that the additional screening was justified to identify those who pose a threat. (Donal, 2016)

In a speech on August 31, 2016 Trump vowed to "suspend the issuance of visas" to "places like Syria and Libya". On September 4 vice presidential candidate Mike Pence defended the Trump-Pence ticket's plan to suspend immigration from countries or regions of the world with a history of terrorism on Meet the Press. He gave Syria as an example of such a country or region: "Donald Trump and I believe that we should suspend the Syrian refugee program" because, Pence said, Syria was a region of the world that was "imploding into civil war" and 
had "been compromised by terrorism". (Donal, 2016)

In late November following the Ohio State attack, President-elect Trump claimed the attacker was a "Somali refugee who should not have been in" the U.S. The president Donal Trump In early December 2016, he said the attack showed immigration security is national security when stating goals for his administration. The attacker injured 11 before he was killed by police. The attacker was a Somali-born refugee who spent seven years in Pakistan, the country from which he immigrated to the U.S. with his family on a refugee visa. The attacker was a legal permanent resident living in the U.S. reportedly inspired by but not in direct contact with ISIS. According to Pence, M (2016) in an interview given for a feature in the Ohio State student newspaper approximately two months before the attack, the eventual attacker expressed fear about Donald Trump's rhetoric toward Muslims and what it might mean for immigrants and refugees.

In an interview broadcast the day he would sign the order President Trump told the Christian Broadcasting Network (CBN) that Christian refugees would be given priority in terms of refugee status in the United States. After saying that Syrian Christians were "horribly treated" by his predecessor, Barack Obama

According to Flores, R (2016) has cited that the christians make up very small fractions $(0.1 \%$ to $1.5 \%)$ of the Syrian refugees who have registered with the UN High Commission for Refugees in Syria, Jordan, Iraq, and the Lebanon; those registered represent the pool from which the U.S. selects refugees.

António Guterres, then-UN high commissioner for refugees, said in October 2015 that many Syrian Christians have ties to the Christian community in Lebanon and have sought the UN's services in smaller numbers. During 2016 the U.S. had admitted almost as many Christian as Muslim refugees. Pew research also pointed out that over $99 \%$ of admitted Syrian refugees were Muslim and less than 1\% Christian, despite the demographics of Syria being estimated by Pew to be $93 \%$ Muslim and 5\% Christian. Senator Chris Coons (D-DE) accused Trump of spreading "false facts" and "alternative facts". (Lemire, 2017)

In January 2016, the Department of Justice (DOJ), on request of the Senate Subcommittee on Immigration and the National Interest, provided a list of 580 public international terrorism and terrorism-related convictions from September 11, 2001 through the end of 2014.

According to Smith, M (2017) Based on this data and news reports and other open-source information the committee in June determined that at least 380 among the 580 convicted were foreign-born. The publicly released version of Trump's August 15 speech quoted that report. Alex Nowrasteh of the Cato Institute said the list of 580 convictions shared by DOJ was problematic in that "241 of the 580 convictions ( 42 percent) were not even for terrorism offences"; they started with a terrorism tip but ended up with a non-terrorism charge like "receiving stolen cereal".

The day after Executive Order 13780 was signed, Ohio Congressman Bill Johnson said 60 individuals of the 380 foreign-born individuals or 580 total individuals ( $16 \%$ or $10 \%$, respectively) were from the seven countries implicated by Executive Order 13769, but because Iraq is not among the six countries implicated in Executive Order 13780, Johnson suggested the number may be lower than 60 for countries implicated by that executive order. Nowrasteh notes 40 of the 580 individuals $(6.9 \%)$ were foreign-born immigrants or non-immigrants convicted of planning, attempting, or carrying out terrorist attacks on U.S. soil (his analysis does not specify whether any, some, or all 40 are from the six or seven countries specified by executive orders 13780 or 13769). He contrasts this figure with EO 13780's statement that " since 2001, hundreds of persons born abroad have been convicted of terrorismrelated crimes in the United States", which he says requires including planned acts outside the United States" because "If the people counted as 'terrorism-related' convictions were really convicted of planning, attempting, or carrying out a terrorist attack on U.S. soil then supporters of Trump's executive order would call them 'terrorism convictions' and exclude the (descriptor) 'related'." (Rogin, 2017)

\section{US policy on visitors, immigrants, and refugees}

Section 3 of the order blocks entry of people from Iran, Iraq, Libya, Somalia, Sudan, Syria, and Yemen, for at least 90 days, regardless of whether or not they hold valid non-diplomatic visas. According Nixon, R (2018) cited that the migration order affects about 218 million people who are citizens of these countries. After 90 days a list of additional countries — not just those specified by a subparagraph of the Immigration and Nationality Act (INA) must be prepared. The cited portion of the INA refers to aliens who have been present in or are nationals of Iraq, Syria, and other countries designated by the Secretary of State. Citing Section 3(c) of the executive order, Deputy Assistant Secretary of State for Consular Affairs Edward J. Ramotowski issued a notice that "provisionally revoke[s] all valid nonimmigrant and immigrant visas of nationals" of the designated countries.

The secretary of homeland security, in consultation with the secretary of state and the director of national intelligence, must conduct a review to determine the information needed from any country to adjudicate any visa, admission, or other benefit under the INA. Within 30 days the secretary of homeland security must list countries that do not provide adequate information. The foreign governments then have 60 days to provide the information on their nationals after which the secretary of homeland security must submit to the president a list of countries recommended for inclusion on a presidential proclamation that would prohibit the entry of foreign nationals from 
countries that do not provide the information.(Bier, 2017)

Section 5 suspends the U.S. Refugee Admissions Program (USRAP) for at least 120 days but stipulates that the program can be resumed for citizens of the specified countries if the secretary of state, secretary of homeland security and the director of national intelligence agree to do so. The suspension for Syrian refugees is indefinite. The number of new refugees allowed in 2017 is capped to 50,000 (reduced from 110,000). After the resumption of USRAP refugee applications will be prioritized based on religion-based persecutions only in the case that the religion of the individual is a minority religion in that country.

The order said that the secretaries of state and homeland security may, on a case-by-case basis and when in the national interest, issue visas or other immigration benefits to nationals of countries for which visas and benefits are otherwise blocked. Almasy, S (2017) has cited that the Section 7 calls for an expedited completion and implementation of a biometric entry/exit tracking system for all travelers coming into the United States, without reference to whether they are foreigners or not. (The similar provision in Section 8 of Executive Order 13780 is limited to in-scope travelers, which in 2016 were defined by DHS with respect to biometric entry/exit as all nonU.S. citizens with the ages of 14-79. Executive Order 13780 at $\S$ Effect) Section 7 orders DHS to follow the recommendation of the National Commission on Terrorist Attacks Upon the United States, commonly known as the 9/11 Commission, to create and implement the biometric entry/exit system. (Executive Order The 9/11 Commission Report at page 389)

Secretary of Homeland Security John Kelly has stated to Congress that DHS is considering a requirement that refugees and visa applicants reveal social media passwords as part of security screening. The idea was one of many to strengthen border security, as well as requesting financial records. In 2011 the Obama administration released a memo revealing a similar plan to vet social media accounts for visa applicants. John Kelly has stated that the temporary ban is important and that the DHS is developing what "extreme vetting" might look like (Visa, Report, 2016)

\section{Green-card holders}

There was some early confusion about the status of green-card holders (i.e., lawful permanent residents). According to the lawsuit filed by the states of Washington and Minnesota, dated February 3, 2017 the government had changed its position five times to date Initially, on the evening of Friday January 27, the Department of Homeland Security sent out a guidance to airlines stated "lawful permanent residents are not included and may continue to travel to the USA". CNN reported that it was overruled by the White House overnight. Early Saturday, January 28, the Department of Homeland Security's acting press secretary Gillian Christensen said in an e-mail to Reuters that the order barred green-card holders from the affected countries. By Saturday afternoon White House officials said they would need a case-by-case waiver to return. On Sunday White House chief of staff Reince Priebus said that green-card holders would not be prevented from returning to the United States. (NPR, 2017) According to the Associated Press no green-card holders were ultimately denied entry to the U.S. although several initially spent "long hours" in detention. On January 29, 2017 Secretary of Homeland Security John Kelly deemed entry of lawful permanent residents into the U.S. to be "in the national interest" exempting them from the ban according to the provisions of the executive order. On February 1, White House counsel Don McGahn issued a memorandum to the heads of the departments of State, Justice, and Homeland Security clarifying that the banprovisions of the executive order do not apply to lawful permanent residents. Press Secretary Sean Spicer said that green-card holders from affected countries "no longer need a waiver because, if they are a legal permanent resident, they won't need it anymore". (Rogin, 2017)

\section{Dual citizens}

There was similar confusion about whether the order affected dual citizens of a banned country and a non-banned country. The State Department said that the order did not affect U.S. citizens who also hold citizenship of one of the seven banned countries. On January 28, the State Department stated that other travelers with dual nationality of one of these countries - for example, an Iranian who also holds a Canadian passport — would not be permitted to enter. However, the International Air Transport Association told their airlines that dual nationals who hold a passport from a non-banned country would be allowed in.

The United Kingdom's Foreign and Commonwealth Office issued a press release that the restrictions apply to those traveling from the listed countries not those that merely have their citizenship The confusion led companies and institutions to take a more cautious approach; for example, Google told its dual-national employees to stay in the United States until more clarity could be provided. On January 31, the State Department updated the restrictions to allow persons holding dual citizenship to enter the US provided they possessed a US visa and entered using a passport from an unrestricted country. 


\section{Reason behind US Visa Ban \\ Terrorism}

Trump's stated reason for issuing the executive order was to prevent terrorism. The Fabbian , J (2018) has cited an internal report compiled by the U.S. Department of Homeland Security Intelligence and Analysis Unit, however, concluded that people from the seven nations affected by the travel ban pose no increased terror risk. The report found that "country of citizenship is unlikely to be a reliable indicator of potential terrorist activity" and that few individuals from the seven affected countries access the U.S. in any case, since the State Department grants a small number of visas to citizens of those countries."

The report found that of 82 people determined to have inspired by a foreign terrorist organization "to carry out or try to carry out an attack in the United States, just over half were U.S. citizens born in the United States," while the rest came from a group of 26 countries, only two of which were among the seven nations included in the ban. White House and DHS officials downplayed the significance of the report, saying it was only a draft.

The New York Times reported that "for an action aimed at terrorism, the order appeared to garner little or no support among experts and former officials of every political stripe with experience in the field." Lacapria, K (2017) have cited how experts on terrorism, such as Charles Kurzman of the University of North Carolina, Brian Michael Jenkins of the RAND Corporation, and Daniel Benjamin of Dartmouth College, formerly the State Department's top counterterrorism official. Benjamin said that the order was unlikely to reduce the terrorist threat, and "many experts believe the order's unintended consequences will make the threat worse." Kurzman noted that since the September 11 attacks in 2001, no one has been killed in the U.S. in a terrorist attack by anyone who emigrated from or whose parents emigrated from the seven affected countries. Jenkins explained that of the 147 Jihadist plots and attacks since 9/11, 105 were perpetrated by U.S. citizens and 20 involved legal permanent residents. "In other words, 85 percent of the terrorists lived in the U.S. a long time before carrying out an attackthey were radicalized within the nation's borders." Jenkins went on to say: "Had this temporary prohibition been in effect since 9/11, how many lives would have been saved Not one." While Jenkins conceded that there were two individuals whose entry would have been prevented had the ban been in place since $9 / 11$, both were in the country for years prior to engaging in terrorist related activities. According to Jenkins, the "... failure to identify these individuals before they entered the United States is not a flaw in the vetting process; it is our inability to predict human behavior years into the future."

According to The New York Times reporter Scott Shane, the seven countries in the executive order had a "random quality"; the list excluded Saudi Arabia and Egypt (where many jihadist groups were founded) and Pakistan and Afghanistan (where extremism has a long history, and which have "produced militants who have occasionally reached the United States").

Benjamin stated that the order might be counterproductive in terms of counterterrorism cooperation and feeding into "the jihadist narrative" of a West at war with Islam. Jonathan Schanzer of the conservative Foundation for the Defense of Democracies said that "The order appears to be based mainly on a campaign promise," and did not appear to be tied to any effort to improve vetting or other procedures.

A 2018 paper by scholars at the Immigration Policy Lab at Stanford University found that Trump's refugee ban (which caused a 66\% reduction in refugee resettlement) had no impact on crime rates. (Marcin, 2017)

\section{Number of affected people}

On January 30, Trump said on Twitter "Only 109 people ... were detained and held for questioning"; Homeland Security officials later said this number referred to the initial hours of the order's implementation, On January 31 , Customs and Border Protection (CBP) reported that 721 people were detained or denied boarding under the order; CBP also reported 1,060 waivers for green-card holders had been processed; 75 waivers had been granted for persons with immigrant and nonimmigrant visas; and 872 waivers for refugees had been granted. On February 23 , the Justice Department provided the ACLU with a list of 746 people who were detained or processed by CBP during the twenty-six hours from Judge Ann Donnelly's ruling at 9:37pm on January 28 to 11:59pm on January 29; the ACLU has identified at least 10 people meeting this description who are not on the list they received. Detentions continued at Chicago's O'Hare airport on January 30, 2017.

The effect of the order was far broader, however, than the number of people detained. In terms of barred visaholders, the federal government reported that more than "100,000 visas for foreigners inside and outside the United States have also been revoked, at least temporarily." The Washington Post fact-checker, citing State Department figures, reported that 60,000 U.S. visas were issued in the seven affected countries in fiscal year 2015. The New York Times reported that 86,000 nonimmigrant, temporary visas (mostly for tourism, business travel, temporary work, or education) has been granted to citizens in the seven affected countries in the 2015 fiscal year. The executive order also barred people from the seven countries from obtaining new immigrant visas. In 2015, 52,365 people from the seven affected countries had been issued green cards (which are typically awarded soon after the arrival of an immigrant visa-holder to the United States); "[i]n general, about half of recent new legal permanent residents are new arrivals to the country, and the other half had their status adjusted after living in the United 
States."

In the weeks of 2017 prior to the executive order, the U.S. admitted approximately 1,800 refugees per week (total) from the seven countries covered by the order. While the executive order was in effect, the U.S. received two refugees from those countries. (USDS,2017)

\section{Impact on U.S. industry}

Google called its traveling employees back to the U.S. in case the order prevented them from returning. About 100 of the company's employees were thought to be affected by the order. Google CEO Sundar Pichai wrote in a letter to his staff that "it's painful to see the personal cost of this executive order on our colleagues. We've always made our view on immigration issues known publicly and will continue to do so." According to Barbash, F (2071) has put that the Amazon.com Inc., citing disruption in travel for its employees, and Expedia Inc., citing impact to its customers and refund costs, filed declarations in support of the states of Washington and Minnesota in their case against the executive order, State of Washington v. Trump.

However, Committee for Economic Development CEO Steve Odland-and several other executives and analysts commented that the order will not lead to significant changes in IT hiring practices among US companies, since the countries affected are not the primary source of foreign talent. According to the Hill "a cross-section of legal experts and travel advocates" say that the order "could have a chilling effect on U.S. tourism, global business and enrollment in American universities", (Johnson, 2015)

One effect of Trump's election and policies, and in particular, Trump's executive order, is the "Trump Slump" on the U.S. tourism industry, which contributed \$1.47 trillion to the country's GDP in 2014. As reported by Frommer's, according to Global Business Travel Association, as well as local tourist offices, with policies such as Executive Order 13769 making foreigners feeling less welcome, fewer tourists began traveling to the U.S., with all foreign tourism down $6.8 \%$, online searches for flights from foreign countries down $17 \%$, and foreign business travel dropping by $\$ 185$ million during the first week of the immigration suspension Economic Research Firm Oxford Economics found that Los Angeles County could lose 800,000 visitors - who would otherwise account for $\$ 736$ million in tourism spending - as a direct result of the ban. (Goodman, 2017)

\section{Impact on education}

Many universities were impacted by the issuance of the travel ban. One example is Bennington College. Since nearly twenty percent of students are from around the world, some students were not allowed to return. Even students who planned to attend this college in the future were unable to Universities like New York University, updated its students on each order of the travel ban to keep students educated on what they can do if they are affected by the order. Boyer, D (2017) has cited that many university administrators believe that due to President Trump's view on immigration; students abroad have become reluctant to study in the United States.

Students that have the F1 visa are put at risk with this executive order. Since F1 visas only allow these visa holders one-entry into the United States, this executive order may not allow these individuals to come back if they decide to leave the country for a school break. Due to the ban, the students on F1 visas may not be able to see their families for several years especially if their parents cannot enter the United States as a result of the ban.

\section{Timeline}

Year Month Day Events Details

$201701 \quad 27$ Issuance of executive order

20170128 Release of two deported Once the ban had started, 2 individuals were released from travelers Customs and Border Protection

$201701 \quad 29$ National warrant granted to

$201703 \quad 06 \quad$ A new executive order

$201707 \quad 19$ Supreme Court gives immunity for some relatives

Supreme Court upholds third
26
A New York federal judge accepted a request from the American Civil Liberties Union to protest those stranded in airports.

People who have green cards and visas were freed. Iraq is removed from the order. See Executive Order 13780 for details.

Includes grandparents, grandchildren, brothers-in-law, sisters-in-law, nieces, nephews, aunts, and uncles of anyone in the United States. 


\section{Conclusion}

According to US Census Bureau data (2019), Africa has the fastest-growing number of immigrants in the US, with Nigerians making up the largest group within this population. "(Nigerian Americans) are a very successful class of immigrants," says US Home Land Security Report of 2018, "Over 29\% of Nigerian Americans over the age of 25 holds a graduate degree, which is significantly higher than the rest of the US population, where only $11 \%$ of Americans hold a graduate degree. So, (the ban) is not because they don't already have a presence in the US and aren't already making a contribution to society...That really only leaves one explanation."

While the Trump administration has not presented a particularly nuanced policy towards Africa, there has been a renewed emphasis on business and trade in recent years, predominately with Nigeria which boasts Africa's largest growing economy. Many analysis of International Diplomacy has indicated that this business- and services obtain in US from Nigeria is likely to be damaged as a result of the new travel ban.

\section{Recommendations}

Nigeria as a country need to observe the following issues:

i. $\quad$ Nigerian government need put a good strategy in terms of intensifying restrictions on US companies or US persons doing business in Nigeria," The Nigerian economy may also take a hit from the inside: "The government must shown a willingness to put nationalist pride priorities ahead of economic common sense. So that the dignity of Nigeria citizens should not be relegated among the nation of the world.

ii. Nigerian government at all level should take the issue of insecurity at priority agenda by putting committed security strategic plan to address the issues of Boko Haram in the North East in States like Borno, Yobe and Adamawa while issues of Kidnapping, bandit in the North West in states like Zamfara, Katsina and Kaduna, army robbery and kidnapping in South West in state like Lagos, Ogun, Osun, Eketi and the issue of Herders and Farmers crisis in North Central in state like Benue, Nasarawa and Plateau State.

iii. Nigeria government need to establish bilateral relationship with other potential powerful countries like China, Russia, France and Germany to developed its economic, technology and Security collaboration to end the menace of insecurity in the country and to initiate new page of economic prosperity to the West African region before 2050.

\section{Reference}

Almasy, Steve; Simon, Darran (March 30, 2017). "A timeline of President Trump's travel bans". CNN. Retrieved July 30, 2019

Arango, Tim (July 12, 2011). "Visa Delays Put Iraqis Who Aided U.S. in Fear". The New York Times. Retrieved February 7, 2017

"Arrivals by State and Nationality as of January 31, 2017" (Microsoft Excel). US Department of State. January 31 , 2017.

Bier, David (December 14, 2017). "Trump's Muslim Ban is Working, Muslim Immigration Slumps". Newsweek. Retrieved July 30, 2019

Bier, David (March 17, 2017). "Court Rules the President Violated the 1965 Law with Executive Order". Cato Institute.

Bush, Daniel (November 10, 2016). "Read President-elect Donald Trump's plan for his first 100 days". PBS. Retrieved February 4, 2017.

Bender, Bryan; Andrew, Hanna (December 1, 2016). "Trump picks General 'Mad Dog' Mattis as defense secretary". Politico. Retrieved January 31, 2017

Boyle, Danny (January 20, 2016). "BBC journalist stopped from boarding plane to America over Iranian dualnationality - Telegraph". The Daily Telegraph. Retrieved March 22, 2017. But the new restrictions mean anybody who has travelled to Iran, Iraq, Syria and Sudan since 2011 will have to apply for a visa.

Boyer, Dave (January 25, 2017). "Trump executive order to stem refugees from 'terror-prone' regions". The Washington Times. Washington, D.C. Retrieved January 30, 2017.

Blaine, Kyle; Horowitz, Julia (January 30, 2017). "How the Trump administration chose the 7 countries in the immigration executive order". CNN.

"DHS Announces Further Travel Restrictions for the Visa Waiver Program" (Press release). Department of Homeland Security. February 18, 2016. Retrieved February 11, 2017.

DonaldJTrump.com. Retrieved January 30, 2017. my administration will immediately pursue the following ... actions to restore security ... suspend immigration from terror-prone regions where vetting cannot safely occur.

Donald, Trump (August 15, 2016) Full Text of Donald Trump's Speech on Fighting Terrorism (Speech) Youngstown, Ohio.

Donald J. Trump (December 7, 2015). "Presidential Candidate Donald Trump Rally" (Online Video). Mount 
Pleasant, South Carolina: C-SPAN. Retrieved February 1, 2017. [I am] calling for a total and complete shutdown of Muslims entering the United States until our country's representatives can figure out what the hell is going on.

Executive Order 13769 of January 27, 2017: Protecting the Nation From Foreign Terrorist Entry Into the United States. Executive Office of the President. 82 FR 8977-8982. February 1, 2017.

Executive Order 13769 of January 27, 2017: Protecting the Nation From Foreign Terrorist Entry Into the United States. Executive Office of the President. 82 FR 8977-8982. February 1, 2017.

"Federal Judge Stays Trump Travel Order, But Many Visas Already Revoked". NPR. February 3, 2017. The State Department said today "roughly 60,000 individuals' visas were provisionally revoked" as a result of Trump's Jan. 27 executive order barring refugees from seven countries.

Fabian, Jordan (January 31, 2017). "Spicer: Trump executive order 'not a travel ban'". The Hill. Retrieved July 30 , 2019.

Flores, Reena (November 30, 2016). "Donald Trump tweets about Ohio State University stabbing attack". CBS News

Goodman, Jack (January 30, 2017). "US travel ban: Why these seven countries?". BBC News. Retrieved February 2,2017

"H.R.158 - Visa Waiver Program Improvement and Terrorist Travel Prevention Act of 2015". Congress.gov. 2015. Retrieved January 31, 2017.

Johnson, Jenna (December 7, 2015). "Trump calls for 'total and complete shutdown of Muslims entering the United States"'. The Washington Post. Retrieved December 12, 2018.

Kessler, Glenn (February 7, 2017). "Trump's claim that Obama first 'identified' the 7 countries in his travel ban". The Washington Post. Retrieved February 12, 2017

"US travel ban: Trump puts restrictions on six more countries". BBC News. January 31, 2020. Retrieved January $31,2020$.

US expands travel ban to include N Korea, BBC "Mr Trump's original ban was highly controversial, as it affected six majority-Muslim countries, and was widely labelled a 'Muslim ban'."

LaCapria, Kim (January 30, 2017). "Wherever Visa Is Accepted". Snopes.com. Retrieved January 31, 2017.

Lemire, Jonathan (December 8, 2017). "Trump meets with Ohio State victims, taking on somber duty". Associated Press.

Taylor, Jessica (December 7, 2015). "Trump Calls For 'Total And Complete Shutdown Of Muslims Entering' U.S." NPR. Retrieved December 12, 2018.

"Report of the Visa Office 2016". Bureau of Consular Affairs, U.S. Department of State. Archived from the original on February 4, 2017. Retrieved February 4, 2017.

Marcin, Tim (June 5, 2017). "A Travel Ban or Not? Donald Trump and Sean Spicer Don't always agree on how to describe Policy". Newsweek. Retrieved July 30, 2019.

Barbash, Fred (May 9, 2017). "Muslim ban language suddenly disappears from Trump campaign website after Spicer questioned". Washington Post. Retrieved July 30, 2019.

Lemire, Jonathan; Mascaro, Lisa; Colvin, Jill (January 10, 2020). "White House considering dramatic expansion of travel ban". Associated Press.

Greenwood, Max (January 28, 2017). "ACLU sues White House over immigration ban". The Hill. Retrieved January 29, 2017.

Gladstone, Rick; Sugiyama, Satoshi (July 1, 2018). "Trump's Travel Ban: How It Works and Who Is Affected". The New York Times. ISSN 0362-4331. Retrieved November 9, 2019.

Niayesh, Vahid. "Statistics show that Trump's "travel ban" was always a Muslim ban". Quartz. Retrieved November 9, 2019.

Nixon, Ron (January 20, 2018). "Travel Ban Caught Homeland Security by Surprise, Report Concludes". The New York Times. p. A16. Retrieved March 12, 2018.

Rogin, Josh (February 4, 2017). "Analysis: Inside the White House-Cabinet battle over Trump's immigration order". Chicago Tribune.

Park, Haeyoun; Yourish, Karen; Gardiner, Harris (February 6, 2017). "In One Facebook Post, Three Misleading Statements by President Trump About His Immigration Order". The New York Times. Retrieved February 8, 2017.

Thrush, Glenn (February 24, 2017). "Trump at CPAC: Right's Unlikely Hero Renews Attack on Press". The New York Times

Preston, Julia (June 18, 2016). "Many What-Ifs in Donald Trump's Plan for Migrants". The New York Times. Retrieved October 21, 2017.

"Trump expected to order temporary ban on refugees". Reuters. January 25, 2017. Retrieved January $28,2017$.

Trump, Donald J. (December 7, 2015). "Donald J. Trump Statement on Preventing Muslim Immigration". Donald J. Trump for President, Inc. Archived from the original on May 8, 2017. 
Trump, Donald (August 31, 2016). Presidential Candidate Donald Trump Remarks on Immigration Policy (Speech). C-SPAN. Event occurs at 56:42.

"Trump renews call for Muslim ban in wake of Orlando attack, challenges Clinton to say 'radical Islamic terrorism"'. Business Insider. June 12, 2016.

"Pence once called Trump's Muslim ban 'unconstitutional'. He now applauds a ban on refugees". The Washington Post. Retrieved January 28, 2017

Pence, Mike (September 4, 2016). "Meet the Press" (Transcript) (Interview). Interviewed by Chuck Todd. NBC News

Tafani, Joseph (August 16, 2016). "What Donald Trump means when he proposes 'extreme vetting' for would-be immigrants". Los Angeles Times

"Steve Bannon and Reince Priebus' Joint Interview at CPAC". Time. February 23, 2017.

Smith, Mitch; Pérez-Peña, Richard; Goldman, Adam (November 28, 2017). "Suspect Is Killed in Attack at Ohio State University That Injured 11". The New York Times.

Qiu, Linda (January 30, 2017). "Why comparing Trump's and Obama's immigration restrictions is flawed". PolitiFact.com. Tampa Bay Times. Retrieved January 31, 2017. 